general are undoubtedly popular with many people, but the B.B.C. are interested in any evidence showing that such talks have a good effect.

Yours faithfully,

THEODORE H. WhitTINGTON,

146, Harley Street, W.1

May 27, 1937.

\title{
OBITUARY
}

\section{N. C. RIDLEY}

Ophthalmology in the Midlands and more especially some of his nearest and dearest friends in that profession have suffered a great and irretrievable loss in the passing of Mr. N. C. Ridley of Leicester. For over forty years he had conducted one of the largest practices in the Midlands with great honour and distinction to himself and has given of his best to many thousands of patients, to whom his name was a household word and who will never cease to remember the benefits they received from his exceptional skill and long experience. His invariable and infectious cheerfulness during a long life of bodily affliction was an example to us all, and those who knew him intimately were astonished at his pluck in face of all his disabilities. He was perhaps best known to the members of the Oxford Ophthalmological Congress where his genial presence will be very much missed.

He was a founder and an original member of the Council of the Congress, and he never, by any chance, missed the Annual Meeting. He was also a founder and Past President (1915-1917) of the Midland Ophthalmological Society and the members of that Society have reason to be grateful to him for providing many excellent meetings at Leicester.

Nicholas Charles Ridley was born April 6, 1863, the eldest son of the Rev. Charles George Ridley, Vicar of Bratoft, Lincolnshire. He was educated at Boston and proceeded to St. Mary's Hospital, where he qualified and then acted as House Surgeon to the late Mr. Edmund Owen. He entered the Navy as Surgeon, being second out of 40 examined, but unfortunately after a few years' service was invalided out, on account of ankylosis of a knee due to pyogenic infection following fever.

$\mathrm{He}$ then specialized in ophthalmology and became Clinical Assistant to Mr. Silcock at Moorfields, afterwards becoming temporary Curator for five months in the absence of $\mathrm{Mr}$. Treacher 


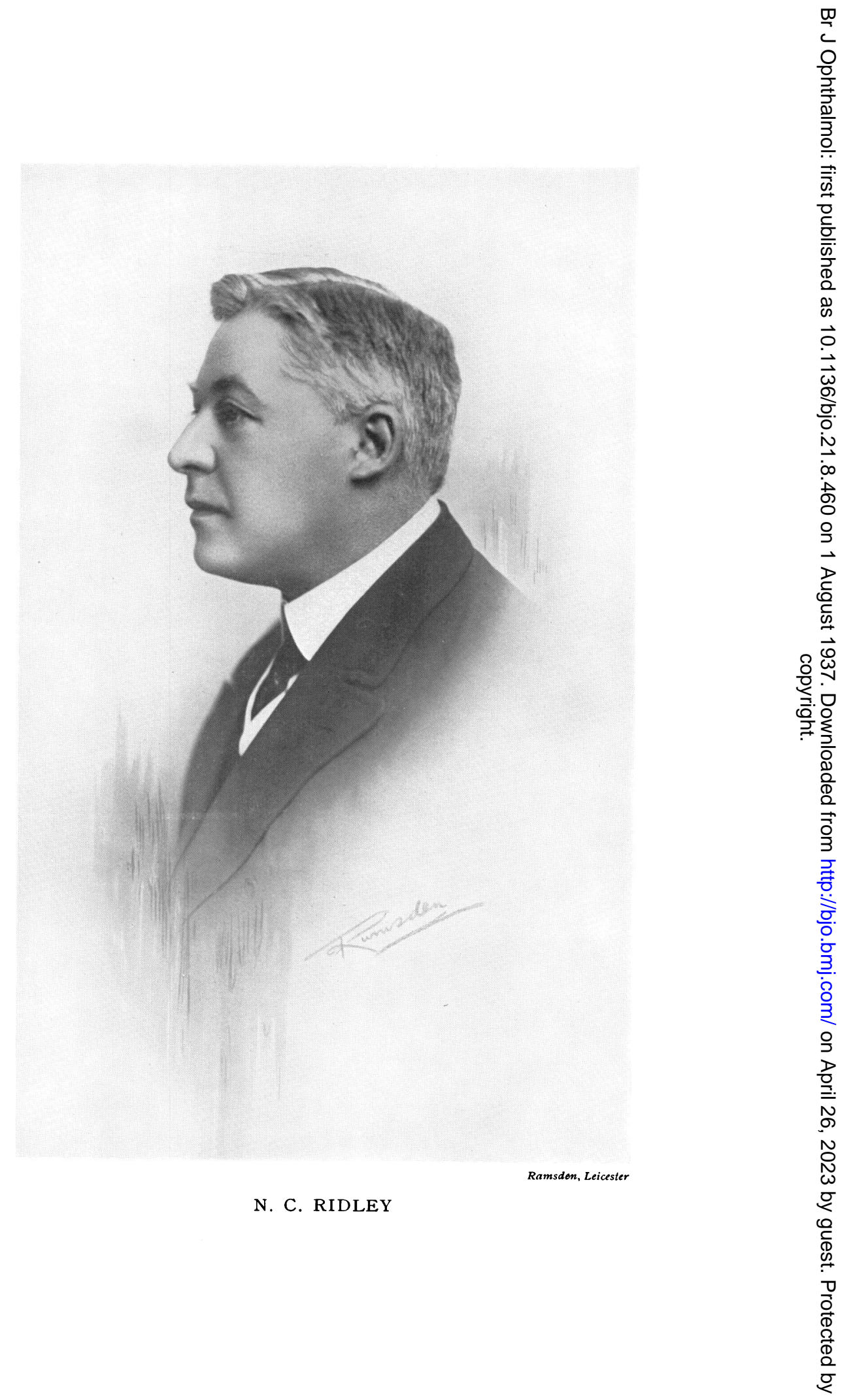


Collins. Succeeding Mr. Hodges at Leicester, he passed the primary and final F.R.C.S.Eng. within six months and was appointed Ophthalmic Surgeon to Leicester Royal Infirmary where he was the sole Ophthalmic Surgeon for 28 years.

$\mathrm{He}$ was very fond of yachting and frequently accompanied the late Devereux Marshall in his cruises. At the outbreak of the Great War he volunteered for active service but was refused on account of his disability.

He died in harness, as he would have wished to die, on June 8 , 1937, the cause of death being cerebral haemorrhage. He was 74 years old. He left two sons, Mr. Harold Ridley who practises as an Ophthalmic Surgeon and Mr. N. C. A. Ridley who is in the Colonial Service in Rhodesia.

\section{NOTES}

Honour Sir H. Lindo Ferguson, C.M.G., M.D., of St. John of Jerusalem.

\section{has been promoted Commander of the Order}

Surgical Course PROFESSOR TERRIEN announces the cus-
tomary Autumn course in surgery at the Hôtel Dieu. This starts on October 15 and consists of twelve sessions, with a course of operative surgery, practical demonstrations and a visit to the Radium Institute. A certificate will be awarded to each pupil at the end of the course.

\section{FUTURE ARRANGEMENTS}

\section{7}

October 1-Midland Ophthalmological Society, at the Eye Hospital, Birmingham (Annual Meeting).

December 7.- Midland Ophthalmological Society, at Birmingham Eye Hospital (Middlemore Lecture). 